\title{
Notch Inhibition in Cancer: Challenges and Opportunities
}

\author{
Doriano Fabbro, Michael Bauer, Maximilien Murone, and Rajwinder Lehal ${ }^{\star}$
}

\begin{abstract}
Notch is a key oncogenic pathway in several human cancers and to date, no targeted treatment of Notch activated cancers is available to patients. Therapeutic targeting of Notch has been an unresolved challenge due to severe on-target dose limiting toxicities associated with pan-Notch inhibition by either $\gamma$-secretase inhibitors or receptor/ligand targeting MAbs. At Cellestia Biotech, we have identified novel series of small molecule inhibitors of the Notch transcription complex. These molecules act as pan-Notch inhibitors and do not cause toxicities commonly associated with first- and second- generation Notch inhibitors currently tested in the clinic, thus providing a novel and unique opportunity to address a high unmet medical need. Our lead molecule, CB-103 is currently being investigated in Phase-1 dose escalation in cancer patients. Cellestia Biothech is further expanding its medicinal chemistry activities advancing the development of novel molecules for targeting transcription factors in cancer as well as non-cancer indications.
\end{abstract}

Keywords: CB-103 $\cdot$ Cancer $\cdot$ Notch $\cdot \gamma$-Secretase inhibitors

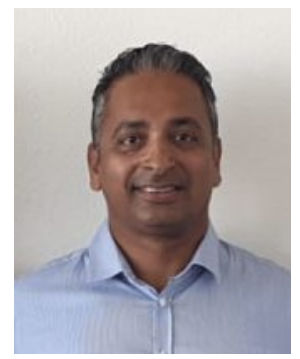

Rajwinder Lehal serves as CSO and Board member at Cellestia Biotech. He spun-out Cellestia Biotech from EPFL in Lausanne based on his 12 years of research in cancer and drug discovery. Rajwinder graduated at University of Toronto before moving to EPFL. At the EPFL he established a drug discovery platform with the goal to target transcription factors and where he discovered CB-103, the lead molecule from Cellestia's drug development program, which is currently in Phase-1 clinical trial.

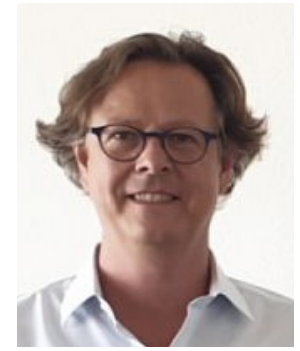

Michael Bauer is co-founder and CEO at Cellestia since 2015 and a senior drug development professional with more than 20 years' experience in the life sciences industry. He has served in senior leadership positions across disciplines including clinical and preclinical drug development, project \& portfolio management, regulatory affairs and metabolism research. Most recent assignments prior to joining Cellestia were with Novartis Translational Medicine Oncology, and Polyphor Ltd., where he served as Head of Clinical and Preclinical Development.

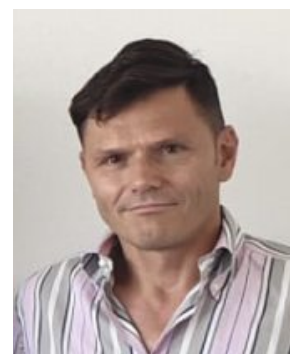

Maximilien Murone joined Cellestia as Chief Operating Officer in 2017 with more than 20 years of experience in several life science companies. Before joining Cellestia, Maximilien served as Managing Director for AdipoGen Life Sciences, and as Associate Director at Debiopharm International SA for 10 years, where he was responsible for managing the pre-clinical portfolio, and in-licensing new oncology programs. Maximilien holds a $\mathrm{PhD}$ from the Swiss Institute

${ }^{*}$ Correspondence: Dr. R. Lehal, E-mail: raj.lehal@cellestia.com

Cellestia Biotech AG, Hochbergerstrasse 60C, 4057-Basel, Switzerland of Experimental Cancer Research, an executive MBA from the Faculty of Business and Economics, HEC Lausanne, and worked as postdoctoral researcher at Genentech, Inc.

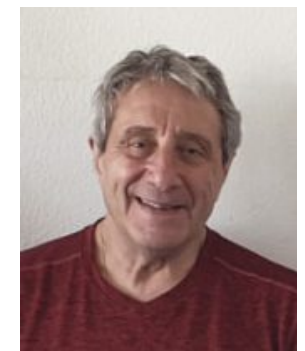

Doriano Fabbro serves at Cellestia Biotech as a senior VP of Research with 30 years of experience in drug discovery (CibaGeigy, Novartis, Piqur Therapeutics and Targimmune). After obtaining his $\mathrm{PhD}$ at the Biocenter Basel he joined the Oncology Drug Discovery of Ciba-Geigy Basel and then Novartis (NIBR) where he held various global functions in the NIBR oncology drug discovery. He later led the Expertise Platform Kinases dedicated to the global kinase drug discovery of all NIBR disease areas. Doriano has contributed to the discovery and development of various marketed protein kinase inhibitors for oncological indications $\left(\right.$ Rydapt $^{\circledR}$, Glivec $^{\circledR}$, Afinitor $^{\circledR}$, Tasigna ${ }^{\circledR}$ and Piqray ${ }^{\circledR}$ ).

\section{Introduction}

Since the discovery of the notched wing phenotype in Drosophila melanogaster due to mutations in the Notch receptors, significant progress has been made to characterize this evolutionarily conserved signaling pathway that is comprised of the four receptors (NOTCH 1-4) and its 5 ligands (DELTA LIKE 1, 3,4 , JAGGED 1-2). ${ }^{[1-8]}$ The Notch pathway with its downstream targets and cross-talk with other development pathways plays a crucial role in cell-fate determination, differentiation, development, tissue patterning, cell proliferation, and death. ${ }^{\text {[9] }}$ As the role of Notch remains tissue- and context-dependent, alterations within this pathway may lead to either a tumor suppressive or an oncogenic phenotype.

\section{Notch Signaling}

Notch receptors are transmembrane proteins consisting of a Notch extracellular domain (NECD), a Notch intracellular domain (NICD) that extends via its transmembrane domain (TM) to the extracellular hetero-dimerization domain (HD). The NECD contains epidermal growth factor (EGF) repeats for the interaction with Notch ligands, a negative regulatory region (NRR) harboring 
the cleavage site S2 for ADAM10 or 17.[10-12] The EGF repeats and NRR region of NECD play an important role in ligand-dependent activation of the pathway by triggering a S3 cleavage of Notch receptors by $\gamma$-secretase complex (GS). ${ }^{[13]}$ The GS mediated cleavage of Notch receptors sheds the NICD into the cytoplasm with subsequent translocation to the nucleus. Due to its role in S3 cleavage mediated activation of Notch signaling, the GS complex has been the main focus for targeting the Notch pathway in cancer (Fig. 1).

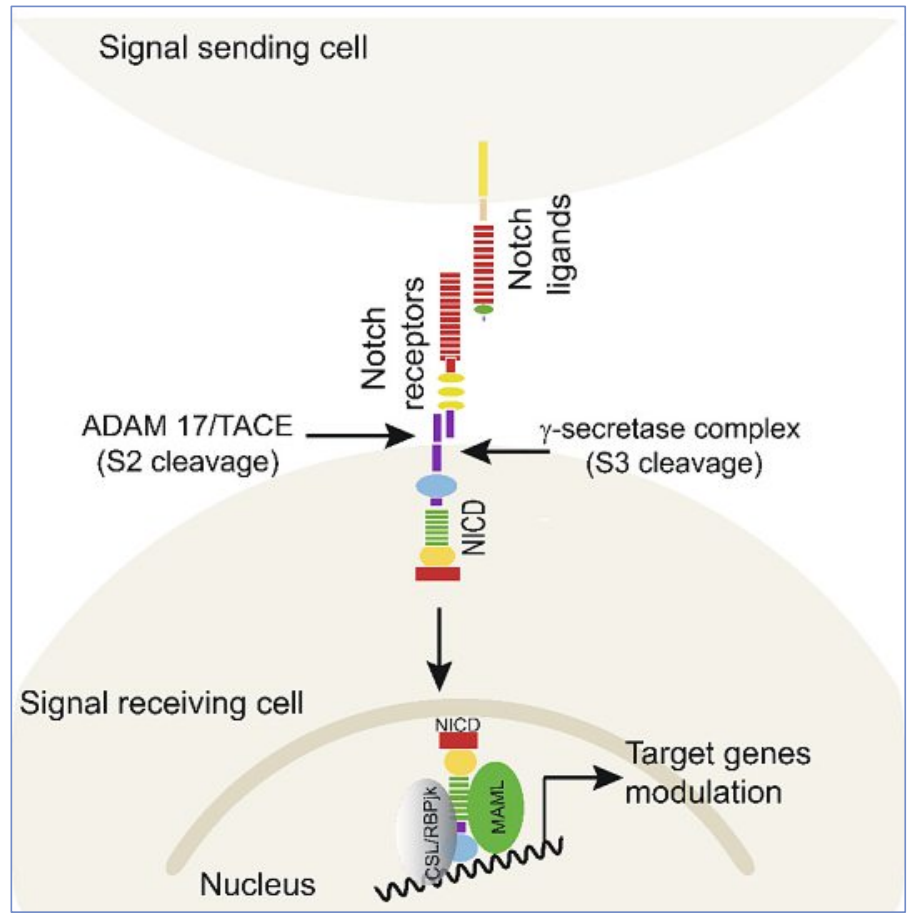

Fig. 1. The Notch pathway. Notch signaling is activated upon ligand receptor interaction on two adjacent cells. This is followed by sequential cleavage of Notch receptors by metalloprotease ADAM17 and $\gamma$-secretase complex generating constitutive active form Notch intracellular domain (NICD). In association with CSL/RBPJ and MAML proteins, NICD forms the core components of Notch transcription complex and regulates transcription of Notch target genes.

The NICD consists of a RBPJ interacting domain (RAM), Ankyrin (ANK) repeats, a transactivation domain and a PEST (Proline, Glutamine, Serine and Threonine) domain. In the absence of Notch signaling, CSL (CBF-1 in mammals; suppressor of hairless in Drosophila; LAG-1 in C. elegans) represses transcription of Notch target genes. ${ }^{[14]}$ Once in the nucleus, the RAM domain of NICD interacts with CSL $^{[15]}$ which is further strengthened by ANK repeats, leading to recruitment of additional co-activators such as MASTER MIND Like 1-3 (MAML1-3) and p300.[16-18] The Notch pathway activation is temporally fine-tuned by the MAML-mediated recruitment of CycC:CDK8 to the CSL/RBPJNICD complex which phosphorylates the PEST domain of NICD causing the FBW7-mediated (F-box and WD repeat domain-containing 7) degradation of the NICD. ${ }^{[19,20]}$ Alteration in the highly context dependent Notch signaling may endow this pathway with either tumor suppressive or oncogenic properties (Fig. 1).

\section{Role of Notch in Development}

The Notch pathway is a conserved signaling cascade that dictates the development of several organs during embryogenesis and in adults. In mammals the role of Notch signaling during embryogenesis is demonstrated by embryonic lethality in Notch1 deficient mouse due to defective vasculogenesis and hematopoiesis. ${ }^{[21]}$ While Notch signaling is dispensable for hematopoietic stem cell maintenance in adults, its activation is responsible for the differ- entiation of early thymic progenitors in favor of $\mathrm{T}$ cells over $\mathrm{B}$ cells $^{[22,23]}$ as well as differentiation of other hematopoietic cell lineages such as splenic marginal zone B cells ${ }^{[24,25]}$ and splenic dendritic cells. ${ }^{[26,27]}$ Notch signaling regulates the development of luminal epithelial cells in the mammary gland ${ }^{[28,29]}$ and in the small intestine, it coordinates the proliferation and differentiation of the intestinal stem cells into absorptive (enterocytes) and secretory lineages (goblet cells, Paneth cells and enterendocrine cells). Genetic and pharmacological inhibition of the Notch pathway in the small intestine skews the differentiation of the intestinal stem cells into excessive goblet cell production, a phenotype referred to as goblet cell metaplasia in mice. ${ }^{[30-32]}$ Thus, complete pan-Notch blockade leads to major gastrointestinal toxicities which often manifests as severe diarrhea and vomiting in the clinic and limits the therapeutic efficacy of pharmacological inhibitors of the pathway.

\section{Oncogenic Role of Notch in Human Cancers}

An oncogenic and causative role for Notch signaling in human cancer was first demonstrated in T cell acute lymphoblastic leukemia (T-ALL) with the discovery of a chromosomal translocation involving the NOTCH1 locus, ${ }^{[33]}$ which leads to a fusion of the NOTCHI gene downstream of the TCR $\beta$ enhancer element causing a constitutive pathway activation. The T-ALL causing role of NOTCH1 was recapitulated in mouse studies by over expression of NICD in hematopoietic stem cells ${ }^{[34]}$ and further confirmed in primary human T-ALL by the identification of gain of function (GOF) mutations clustering in the HD and PEST domains of the NOTCH1 receptor. ${ }^{[35]}$ In addition to T-ALL, GOF mutations in the Notch receptor have also been reported in $25 \%$ of Marginal Zone B cell lymphomas (MZBL) as well as in 10-15\% of Chronic Lymphocytic Leukemias (CLL) and Mantle cell lymphomas (MCL). ${ }^{[36]}$ In relapsed/metastatic adenocystic carcinoma (ACC) about $35 \%$ of patients harbor GOF mutations in NOTCH1, NOTCH 2 and NOTCH3 receptors. ${ }^{[37]}$ Constitutive pathway activation due to chromosomal translocation in $\mathrm{NOTCH1}$ and $\mathrm{NOTCH} 2$ genes have also been reported in $10 \%$ of triple negative breast cancers ${ }^{[38,39]}$ and $56 \%$ of malignant glomous tumors. ${ }^{[40]}$ Activation of Notch signaling by upregulation of ligands and receptors has also been proposed to contribute to resistance to standard of care treatment in relapsed/refractory cancers such as ER+ve ${ }^{[41,42]}$ as well as HER2+ve breast cancers ${ }^{[43-45]}$ (Table 1).

Table 1. A list of frequency of human tumors that harbour gain of function mutations in NOTCH receptor genes (adopted from ref. [1])

\begin{tabular}{|l|l|l|}
\hline Indication & $\begin{array}{l}\text { NOTCH } \\
\text { component }\end{array}$ & $\begin{array}{l}\text { Frequency } \\
\text { of NOTCH } \\
\text { activation }\end{array}$ \\
\hline $\begin{array}{l}\text { T cell acute lymphoblastic } \\
\text { leukemia }\end{array}$ & $\begin{array}{l}\text { NOTCH1 } \\
\text { FBXW7 }\end{array}$ & $\begin{array}{l}50-60 \% \\
12-30 \%\end{array}$ \\
\hline Chronic lymphocytic leukemia & NOTCH1 & $15 \%$ \\
\hline Adenocystic carcinoma & $\begin{array}{l}\text { NOTCH1- } \\
\text { NOTCH4 }\end{array}$ & $35 \%$ \\
\hline Triple negative breast cancer & $\begin{array}{l}\text { NOTCH1- } \\
\text { NOTCH2 }\end{array}$ & $5-10 \%$ \\
\hline Glomus tumors & NOTCH2 & $52 \%$ \\
\hline Mantle cell lymphoma & NOTCH1 & $15 \%$ \\
\hline Marginal zone B cell lymphoma & NOTCH2 & $5-25 \%$ \\
\hline Diffuse large B cell lymphoma & NOTCH1 & $11 \%$ \\
\hline
\end{tabular}




\section{Targeting Notch in Cancer: Opportunities and Challenges}

Given its role in human cancers, the Notch pathway is an attractive target for developing novel anti-cancer therapies. In fact, several pharmaceutical companies have attempted to develop inhibitors of the Notch pathway (Fig. 2, Table 2).

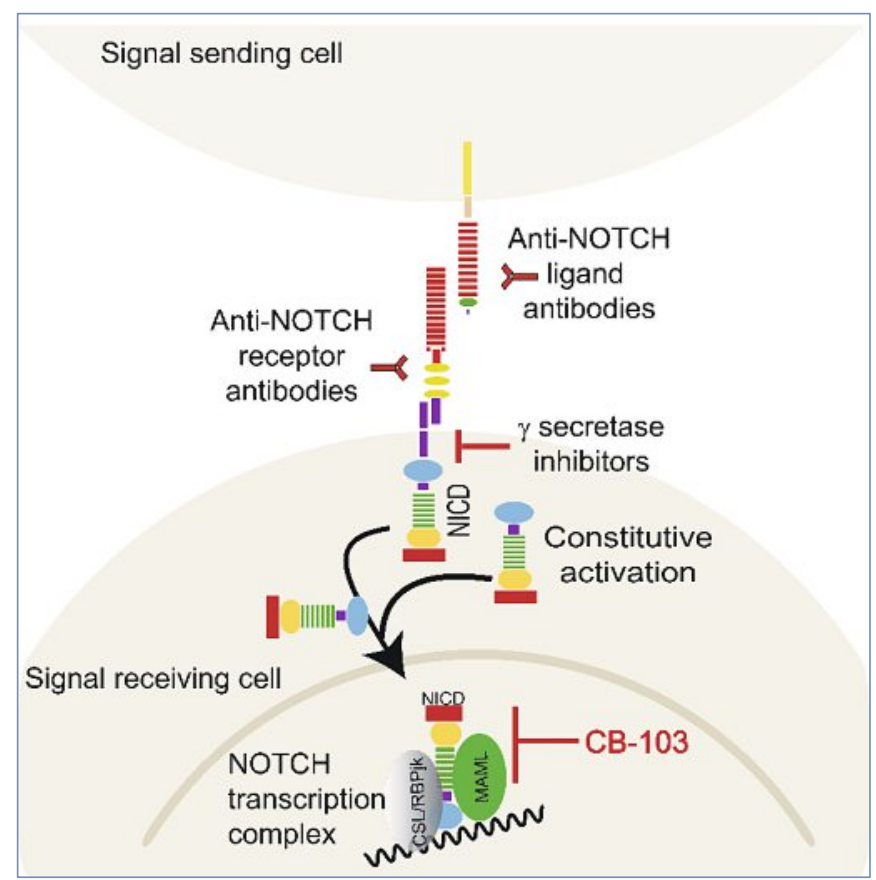

Fig. 2. Therapeutic targeting of the Notch pathway. Mode of action of different Notch targeting therapeutic agents. Anti-NOTCH ligand/receptor antibodies inhibit ligand-receptor mediated pathway activation. The $\gamma$-secretase inhibitors blocks cleavage of NOTCH receptors. CB-103 and its analogs inhibit Notch signaling by directly targeting Notch transcription complex and act as a protein-protein interaction inhibitors.

Table 2. Status of current NOTCH inhibitors.

\begin{tabular}{|l|l|l|}
\hline Target & Inhibitor & Status \\
\hline$\gamma$-secretase complex & AL-101 & Phase II \\
& PF-03084014 & Phase II \\
& RO4929097 & Discontinued \\
MK-0752 & Discontinued \\
\hline Notch receptor/ligand & LY3039478 & unknown \\
\hline & $\begin{array}{l}\text { Demcizumab } \\
\text { Brontictuzumab } \\
\text { (Anti-NOTCH1) }\end{array}$ & Discontinued \\
\hline $\begin{array}{l}\text { Tarextumab } \\
\text { (Anti-NOTCH2/3) }\end{array}$ & Discontinued \\
\hline $\begin{array}{l}\text { Notch transcription } \\
\text { complex }\end{array}$ & $\begin{array}{l}\text { CB-103 } \\
\text { IMR-1 }\end{array}$ & $\begin{array}{l}\text { Phase I } \\
\text { Pre-clinical }\end{array}$ \\
\hline & RIN-1 & Pre-clinical \\
\hline
\end{tabular}

Although there are no FDA approved therapies for Notch inhibition, multiple attempts have been made either using small molecule inhibitors or monoclonal antibodies (e.g. Demcizumab, Tarextumab, GSI MK-0752, R04929097, and PF03084014)[46] which can be categorized into three different classes. These are i)
GS inhibitors (GSIs) blocking Notch signaling by inhibiting the S3 cleavage of Notch receptors, ii) monoclonal antibodies blocking the ligand-receptor interaction or the S2 cleavage of Notch receptors and iii) inhibitors of the Notch transcription complex (NTC). The current status of each of these classes of inhibitors is discussed below (Table 2).

\section{Gamma Secretase Inhibitors (GSIs)}

The GS, an aspartyl protease, which resides in a multiprotein complex, is able to cleave more than 90 proteins including NOTCH1-NOTCH4 receptors. ${ }^{[47]}$ GSIs have been originally developed for the treatment of the Alzheimer's disease and widely used to inhibit Notch signaling. Examples of these GSIs include RO4929097, LY3039478, AL-101 (formerly, BMS-090624), PF03084014 and MK-0752. These GSIs have demonstrated robust pre-clinical but modest clinical activities in cancers with an activated Notch pathway. LY3039478 has demonstrated dose-dependent target engagement in skin biopsies and one partial response (PR) in hormone responsive (ER+ve/PR+ve/HER2-ve) breast cancer patients. ${ }^{[48]}$ LY3039478 has also shown clinical activity in soft tissue sarcoma and gastrointestinal stromal tumors ${ }^{[49]}$ as well as stable disease in $58 \%$ of advanced/metastatic ACC patients. ${ }^{[50]}$ Similar partial response rates have also been observed with other GSIs in melanoma (RO4929097) ${ }^{[51]}$ and triple negative breast cancer (PF-03084014). ${ }^{[52]}$ Most importantly, AL-101 and PF-03084014 achieved complete responses in T-ALL patients harboring activated NOTCH1, validating clinically the Notch pathway as a relevant drug development target ${ }^{[53,54]}$ (ClinicalTrials.gov Identifier: NCT03691207). Despite these early signs of clinical activity, the clinical development of GSIs is marred by severe on-target gastro-intestinal (GI) tract toxicities, most likely due to complete inhibition of Notch signaling as well as to the non-selective inhibition of additional targets of the GS. ${ }^{[55-57]}$ Thus, the doses of GSIs required to achieve inhibition of the Notch pathway in cancer are seriously limited by the GI toxicities highlighting the opportunities and challenges associated with the targeting of the Notch pathway for therapeutic intervention.

\section{Monoclonal Antibodies Inhibiting Notch Signaling}

Advances in the structural biology of the Notch ligands, their receptors and transcriptional activation complex has helped to identify novel targets in the Notch pathway. Structural determination of Notch receptors led to the discovery and development of anti-NOTCH1 and anti-NOTCH2 antibodies that lock these receptors in an 'off' conformation. These antibodies bind to the NRR of the respective receptors and block their S2 cleavage. Preclinical studies using anti-NOTCH1 antibodies showed promising results in their ability to block in vivo tumor growth in xeno-transplant models of human disease. ${ }^{[58]}$ Recently, NOTCH1 and NOTCH2/3 targeting antibodies demonstrated clinical signs of efficacy which were associated with the typical GI tract toxicity observed with GSIs. ${ }^{[59,60]}$ As an alternative strategy, antibody-mediated blockade of Notch ligands has also been investigated in preclinical and clinical studies. For example, blocking antibodies against the Notch ligand DELTA LIKE 4 (DLL4) has been tested in preclinical studies. However, the use of an anti-DLL4 antibody has raised serious safety concerns. The chronic blockade of DLL4 in rats and cynomolgus monkey caused sinusoidal dilation and centrilobular hepatocyte atrophy in the liver. In addition to disrupting normal organ homeostasis, the blockade of DLL4 also caused vascular tumors. ${ }^{[61]}$ In the Phase-1 clinical trials these antibodies led to hypertension and heart failure, thereby impeding further development of these blocking antibodies. ${ }^{[62]}$ Moreover, anti-ligand and anti-receptor antibodies are expected to be ineffective in tumors harboring gene truncations/gene fusions. For example, the 5 ' deletions within the Notchl gene generates a truncated dominant active form of the receptor lacking the NRR region which is the target of anti-Notch1 antibodies. ${ }^{[63]}$ Thus Notch ligand/receptor inhibi- 
tory antibodies will fail in human cancers where Notch signaling is activated due to chromosomal aberrations or due to alternative transcription start sites in the $3^{\prime}$ region of the Notch receptors.

\section{Targeting the Notch Transcription Complex (NTC)}

Thus far targeting of the GS, individual Notch receptors and ligands has failed to yield optimal tumor efficacy partly due to the induction of on-target GI tract toxicity, hypertension and heart failure. Interrupting the Notch pathway by drug-like small molecules targeting the NTC by disrupting protein-protein interaction remains a challenging but viable option to develop Notch targeting therapies. The available X-ray structures of the CSL/RBPJNICD-MAML complex have supported the identification of protein-protein interfaces amenable for targeting of the NTC. In one study, Moellering and colleagues mapped an $\alpha$-helical part of the MAML1 protein responsible for its binding to NICD and developed a dominant negative form of MAML1 to block transcriptional activity of the complex. ${ }^{[64]}$ Other studies showed attempts to target the NTC by small molecule inhibitors, but these programs have remained at the preclinical drug discovery stage. ${ }^{[65,66]}$ One inhibitor (RIN-1) is noteworthy because it blocks the functional interaction between RBPJ and SHARP in the absence of Notch signaling. The SHARP-RBPJ interaction may be exploited therapeutically as SHARP acts as a protein scaffold which induces potent transcriptional repression resembling the knock-out of RBPJ rather than inhibition of Notch signaling. ${ }^{66]}$

Cellestia Biotech has identified and pre-clinically validated a first-in-class orally active small molecule inhibitor, CB-103, that acts as protein-protein interaction inhibitor of the NTC without causing intestinal toxicity. ${ }^{[67]} \mathrm{CB}-103$ is a highly selective panNotch inhibitor with a favorable therapeutic index compared to other Notch targeting inhibitors currently being tested in the clinic. In animal studies, CB-103 has demonstrated anti-cancer activity at well-tolerated doses circumventing the dose limiting toxicities associated with GSIs and monoclonal blocking antibodies. The ability of CB-103 to act as a pan-Notch inhibitor without causing goblet cell metaplasia is linked to its unique mode of action (MoA). Genetic and pharmacological studies have associated GI tract toxicity of Notch inhibitors to the upregulation of the Atoh1 gene which normally induces goblet cell differentiation. Since CB-103 directly targets the NTC, it allows differential gene expression of downstream transcriptional target. In vivo and ex-vivo models of intestinal organoids have shown that while CB-103 effectively inhibits Notch target genes (the Hes family and Olfm4), it does not lead to an upregulation of Atoh1 in the small intestine, thereby sparing the animals from goblet cell metaplasia. ${ }^{[66]}$ This finding has been confirmed in animal toxicology studies. In addition, due to its unique MoA, CB-103 has demonstrated the ability to target a wide spectrum of cancers with Notch activation including tumors harboring chromosomal translocations in the Notch receptors, which are usually resistant to Notch inhibition by GSIs and monoclonal antibodies.[66]

CB-103 is currently being investigated in a Phase- 1 dose escalation study (ClinicalTrials.gov Identifier: NCT03422679) and has been found to be generally well tolerated, in line with expectations based on preclinical testing (unpublished data). The CB-103 clinical program is backed by a comprehensive biomarkers-based approach for the selection of key Notch-driven oncology indications and for monitoring the target engagement (unpublished data). To further capitalize on its asset, the company is planning to initiate Phase- 2 clinical trials with CB-103 as a single agent and in combination therapies. The combination trials are designed based on scientific rationale and supported by pre-clinical data. Based on strong in-house research programs, Cellestia Biotech is further expanding its medicinal chemistry activities and growing its pipeline beyond the lead asset and is advancing development of novel molecules for targeting cancer as well as non-cancer indications.
Cellestia

Biotech AG

CO CELlestia

Cellestia Biotech AG is a clinical stage company, with HQ in Basel and research laboratory in Lausanne, Switzerland. The company is developing first-in-class therapies for cancer by targeting transcription factors. The company is managed by an experienced team of scientists and pharma executives.

\section{Key Figures}

Founding Year

Location

Legal Form

Management team

Strategic Advisor

Scientific Advisors

No of employees

Market capitalization

Key Inventions

Oncology project

\section{Next Milestones}

\section{Contact}

Contact Person

Address

E-mail

Website

\section{4}

Headquarter: Technologie Park, Basel, Switzerland

Corporation (Ltd.)

Dr. Michael Bauer, CEO

Dr. Rajwinder Lehal, CSO

Dr. Florian Vogl, CMO

Dr. Maximilien Murone, COO

Gaudenz von Capeller, CFO

Dr. Doriano Fabbro (Senior VP Research)

\section{David Epstein}

Prof. Douglas Hanahan

Prof. Jon Aster

Prof. Josep Tabernero

12

Privately owned

Developing first-in-class drugs by targeting oncogenic transcription factors.

Completion of Phase-1

Dr. Rajwinder Lehal

Cellestia Biotech AG

Office: Hochbergerstrasse 60C 4057-Basel, Switzerland

raj.lehal@cellestia.com

www.cellestia.com
Received: July 5, 2020

[1] M. Lardelli, J. Dahlstrand, U. Lendahl, Mech. Dev. 1994, 46, 123.

[2] C. Larsson, M. Lardelli, I. White, U. Lendahl, Genomics 1994, 24, 253.

[3] C. E. Lindsell, C. J. Shawber, J. Boulter, G. Weinmaster, Cell 1995, 80, 909.

[4] J. L. Lissemore, W. T. Starmer, Mol. Phylogenet. Evol. 1999, 11, 308.

[5] E. M. Maine, J. L. Lissemore, W. T. Starmer, Mol. Phylogenet. Evol. 1995, 4, 139 .

[6] H. Uyttendaele, G. Marazzi, G. Wu, Q. Yan, D. Sassoon, J. Kitajewski, Development 1996, 122, 2251

[7] G. Weinmaster, V. J. Roberts, G. Lemke, Development 1992, 116, 931

[8] C. Shawber, J. Boulter, C. E. Lindsell, G. Weinmaster, Dev. Biol. 1996, 180, 370 .

[9] S. Artavanis-Tsakonas, M. D. Rand, R. J. Lake, Science 1999, 284, 770. 
[10] W. R. Gordon, M. Roy, D. Vardar-Ulu, M. Garfinkel, M. R. Mansour, J. C. Aster, S. C. Blacklow, Blood 2009, 113, 4381.

[11] W. R. Gordon, D. Vardar Ulu, G. Histen, C. Sanchez-Irizarry, Nat. Struct. Mol. Biol. 2007, 14, 295.

[12] C. Brou, F. Logeat, N. Gupta, C. Bessia, O. LeBail, J. R. Doedens, A. Cumano, P. Roux, R. A. Black, A. Israël, Mol. Cell 2000, 5. 207.

[13] G. Struhl, I. Greenwald, Nature 1999, 398, 522.

[14] H. Y. Kao, P. Ordentlich, N. Koyano-Nakagawa, Z. Tang, M. Downes, C. R. Kintner, R. M. Evans, T. Kadesch, Genes Dev. 1998, 12, 2269.

[15] R. Kopan, M. X. Ilagan, Cell 2009, 137, 216.

[16] M. E. Fortini, S. Artavanis-Tsakonas, Cell 1994, 79, 273.

[17] S. Jarriault, C. Brou, F. Logeat, E. H. Schroeter, R. Kopan, A. Israel, Nature 1995, 377, 355

[18] H. Roehl, M. Bosenberg, R. Blelloch, J. Kimble, Embo. J. 1996, 15, 7002.

[19] C. J. Fryer, J. B. White, K. A. Jones, Mol. Cell 2004, 16, 509.

[20] C. J. Fryer, E. Lamar, I. Turbachova, C. Kintner, K. A. Jones, Genes Dev. 2002, 16, 1397.

[21] A. Robert-Moreno, L. Espinosa, J. L. de la Pompa, A. Bigas, Development $\mathbf{2 0 0 5}, 132,1117$.

[22] F. Radtke, A. Wilson, G. Stark, M. Bauer, J. van Meerwijk, H. R. MacDonald, M. Aguet, Immunity 1999, 10, 547.

[23] U. Koch, E. Fiorini, R. Benedito, V. Besseyrias, K. Schuster-Gossler, M. Pierres, N. R. Manley, A. Duarte, H. R. MacDonald, F. Radtke, J. Exp. Med. 2008, 205, 2515.

[24] T. Saito, S. Chiba, M. Ichikawa, A. Kunisato, T. Asai, K. Shimizu, T. Yamaguchi, G. Yamamoto, S. Seo, K. Kumano, E. Nakagami-Yamaguchi, Y. Hamada, S. Aizama, H. Hirai, Immunity 2003, 18, 675.

[25] K. Hozumi, N. Negishi, D. Suzuki, N. Abe, Nat. Immunol. 2004, 5, 638.

[26] C. Sekine, Y. Moriyama, A. Koyanagi, N. Koyama, H. Ogata, K. Okumura, H. Yagita, Int. Immunol. 2009, 21, 295.

[27] M. L. Caton, M. R. Smith-Raska, B. Reizis, J. Exp. Med. 2007, 204, 1653.

[28] K. D. Buono, G. W. Robinson, C. Martin, S. Shi, P. Stanely, K. Tanigaki, T. Honjo, L. Hennighausen, Dev. Biol. 2006, 293, 565.

[29] T. Bouras, B. Pal, F. Vaillent, G. Harburg, M.-L. Asselin-Labat, S. R. Oakes, G. J. Lindemann, J. E. Visvader, Cell Stem Cell 2008, 3, 429.

[30] J. H. van Es, M. E. van Gijn, O. Riccio, M. van den Born, M. Vooijs, H. Begthel, M. Cozijnsen, S. Robine, D. J. Winton, F. Radtke, H. Clevers, Nature 2005, 435, 959.

[31] O. Riccio, M. E. van Gijn, A. C. Bezdek, L. Pellegrinet, J. H. van Es, U. Zimber-Strobl, L. J. Strobl, T. Honjo, H. Clevers, F. Radtke, EMBO Rep. 2008, 9, 377.

[32] L. Pellegrinet, V. Rodilla, Z. Liu, S. Chen, U. Koch, L. Espinosa, K. H. Kaestner, R. Kopan, J. Lewis, F. Radtke, Gastroenterology 2011, 140, 1230.

[33] L. W. Ellisen, J. Bird, D. C. West, A. L. Soreng, T. C. Reynolds, S. D. Smith, J. Sklar, Cell 1991, 66, 649.

[34] W. S. Pear, J. C. Aster, M. L. Scott, R. P. Hasserjian, B. Soffer, J. Sklar, D. Baltimore, J. Exper. Med. 1996, 183, 2283.

[35] A. P. Weng, A. A. Ferrnado, W. Lee, J. P. Morris 4th, L. B. Silvermann, C. Sanchez-Irizarry, S. C. Blacklow, A. T. Look, J. C. Aster, Science 2004, 306, 269.

[36] J. C. Aster, W. S. Pear, S. C. Blacklow, Annu. Rev. Pathol. 2017, 12, 245.

[37] A. S. Ho, A. Ochoa, G. Jayakumaran, A. Zehir, C. Valero Mayor, J. Tepe, V. Makarov, M. G. Dalin, J. He, M. Bailey, M. Montesion, J. S. Ross, V. A. Miller, L. Chan, I. Ganly, S. Dogan, N. Katabi, P. Tsipouras, P. Ha, N. Agrawal, D. B. Solit, P. A. Futreal, A. K. El Naggar, J. S. Reis-Filho, B. Weigelt, A. L. Ho, N. Schultz, T. A. Chan, L. G. T. Morris, J. Clin. Invest. 2019, 129, 4276

[38] A. Stoeck, S. Lejnine, A. Truong, L. Pan, H. Wang, C. Zang, J. Yuan, C. Ware, J. MacLean, P. W. Garrett-Engele, M. Kluk, J. Laskey, B. B. Haines, C. Moskaluk, L. Zawel, S. Fawell, G. Gilliland, T. Zhang, B. E. Kremer, B. Knoechel, B. E. Bernstein, W. S. Pear, X. S. Liu, J. C. Aster, S. Sathyanarayanan, Cancer Discov. 2014, 4, 1154.

[39] D. R. Robinson, S. Kalyana-Sundaram, Y.-M. Wu, S. Shankar, X. Cao, B. Ateeq, I. A. Asangani, M. Iyer, C. A. Maher, C. S. Grasso, R. J. Lonigro, M. Quist, J. Siddiqui, R. Mehra, X. Jing, T. J. Giordano, M. S. Sabel, C. G. Kleer, N. Palanisamy, R. Natrajan, M. B. Lambros, J. S. Reis-Filho, C. Kumar-Sinha, A. M. Chimmaiyan, Nat. Med. 2011, 17, 1646.

[40] J. M. Mosquera, A. Sboner, L. Zhang, C.-L. Chen, Y.-S. Sung, H.-W. Chen, N. P. Agaram, D. Briskin, B. M. Basha, S. Singer, M. A. Rubin, T. Tuschl, C. R. Antonescu, Genes Chromosomes Cancer 2013, 52, 1075.

[41] L. Gelsomino, S. Panza, C. Giordano, I. Barone, G. Gu, E. Spina, S. Catalano, S. Fuqua, S. Andò, Cancer Lett. 2018, 428, 12.

[42] B. M. Simoes, C. O. O'Brien, R. Eyre, A. Siva, L. Yu, A. Sarmiento-Castro, D. G. Alférez, K. Spence, A. Santiago-Gómez, F. Chemi, A. Acar, A. Gandhi, A. Howell, K. Brennan, L. Rydén, S. Catalano, S. Andó, J. Gee, A. Ucar, A. H. Soms, E. Marangoni, G. Farnie, G. Landberg, S. J. Howell, R. B. Clarke, Cell Rep. 2015, 12, 1968.

[43] D. L. Abravanel, G. K. Belka, T. C. Pan, D. K. Pant, M. A. Collins, C. J. Sterner, L. A. Chodosh, J. Clin. Invest. 2015, 125, 2484.

[44] N. V. Jordan, A. Bardia, B. S. Wittner, C. benes, M. Ligorio, Y. Zheng, M. Yu, T. K. Sundaresan, J. A. Licausi, R. Desai, R. M. O'Keefe, R. Y. Ebright,
M. Boukhali, S. Sil, M. L. Onozato, A. J. Lafrate, R. Kapur, D. Sgroi, D. T. Ting, M. Toner, S. Ramaswamy, W. Haas, S. Maheswaran, D. A. Haber, Nature 2016, 537, 102.

[45] C. Osipo, P. Patel, P. Rizzo, A. G. Clementz, L. Hao, T. E. Golde, L. Miele, Oncogene 2008, 27, 5019.

[46] E. R. Andersson, U. Lendahl, Nat. Rev. Drug Discov. 2014, 13, 357.

[47] A. Haapasalo, D. M. Kovacs, J. Alzheimers Dis. 2011, 25, 3.

[48] C. Massard, A. Azaro, J.-C. Soria, U. Lassen, C. Le Tourneau, D. Sarker, C. Smith, U. Ohnmacht, G. Oakely, B. K. R. Patel, E. S. M. Yuen, K. A. Benhadji, J. Rodon, Ann. Oncol. 2018, 29, 1911.

[49] O. Mir, A. Azaro, J. Merchan, R. Chugh, J. Trent, J. Rodon, U. Ohnmacht, J. T. Diener, C. Smith, E. Yuen, G. J. Oakley III, A. Le Cesne, J.-C. Soria, K. A. Benhadji, C. Massard, Eur. J. Cancer 2018, 103, 88.

[50] C. Even, U. Lassen, J. Merchan, C. Le Tourneau, J.-C. Soria, C. Ferte, F. Ricci, J. T. Diener, E. Yuen, C. Smith, G. J. Oakley III, K. A. Benhadji, C. Massard, Invest. New Drugs 2020, 38, 402.

[51] S. M. Lee, J. Moon, B. G. Redman, T. Chidiac, L. E. Flaherty, Y. Zha, M. Othus, A. Ribas, V. K. Sondak, T. F. Gajewski, K. A. Margolin, Cancer 2015, $121,432$.

[52] M. A. Locatelli, P. Aftimos, E. C. Dees, P. M. LoRusso, M. D. Pegram, A. Awada, B. Huang, R. Cesari, Y. Jiang, M. N. Shaik, K. A. Kern, G. Curigliano, Oncotarget 2017, 8, 2320.

[53] C. Papayannidis, D. J. DeAngelo, W. Stock, B. Huang, M. N. Shaik, R. Cesari, X. Zhang, J. M. Reynolds, P. A. English, M. Ozeck, J. C. Aster, F. Kuo, D. Huang, P. D. Lira, K. R. McLachlan, K. A. Kern, G. Garci-Manero, G. Martinelli, Blood Cancer J. 2015, 5, e350.

[54] B. Knoechel, A. Bhatt, L. Pan, C. S. Pedamallu, E. Severson, A. Gutierrez, D. M. Dorfman, F. C. Kuo, M. Kluk, A. L. Kung, P. Zweidler-McKay, M. Meyerson, S. C. Blacklow, D. J. DeAngelo, J. C. Aster, Cold Spring Harb. Mol. Case Stud. 2015, 1, a000539.

[55] I. Krop, T. Demuth, T. Guthrie, P. Y. Wen, W. P. Mason, P. Chimmaiyan, N. Butowski, M. D. Groves, S. Kesari, S. J. Freedman, S. Blackman, J. Watters, A. Loboda, A. Podtelezhikov, J. Lunceford, C. Chen, M. Giannotti, J. Hing, R. Beckman, P. Lorusso, J. Clin. Oncol. 2012, 30, 2307.

[56] A. W. Tolcher, W. A. Messersmith, S. M. Mikulski, K. P. Papadodoulos, E. L. Kwak, D. G. Gibbon, A. Patnaik, G. S. Falchook, A. Dasari, G. L. Shapiro, J. F. Boylan, Z.-X. Xu, K. Wang, A. Koehler, J. Song, S. A. Middleton, J. Deutsch, M. Demario, R. Kurzrock, J. J. Wheler, J. Clin. Oncol. 2012, 30, 2348.

[57] K. L. Aung, A. B. El-Khoueiry, K. Gelmon, B. Tran, G. Bajaj, B. He, T. Chen, L. Zhu, S. Poojary, S. Basak, Z. Qi, A. Spreafico, B. S. Fischer, J. Desai, Invest. New Drugs 2018, 36, 1026.

[58] Y. Wu, et al., Nature 2010, 464, 1052.

[59] R. Ferrarotto, G. Eckhardt, A. Patnaik, P. LoRusso, L. Faoro, J. V. Heymach, A. M. Kapoun, L. Xu, P. Munster, Ann. Oncol. 2018, 29, 1561.

[60] D. C. Smith, R. Chugh, A. Patnaik, K. P. Papadopoulos, M. Wang, A. M Kapoun, L. Xu, J. Dupont, R. J. Stagg, A. Tolcher, Invest. New Drugs 2019, 37, 722 .

[61] M. Yan, C. A. Callahan, J. C. Beyer, K. P. Allamneni, G. Zhang, J. B. Ridgway, K. Niessen, G. D. Plowman, Nature 2010, 463, E6.

[62] D. C. Smith, P. D. Eisenberg, G. Manikhas, R. Chugh, M. A. Gubens, R. J. Stagg, A. M. Kapoun, L. Xu, J. Dupont, B. Sikic, Clin. Cancer Res. 2014, 20,6295 .

[63] T. D. Ashworth, W. S. Pear, M. Y. Chiang, S. C. Blacklow, J. Mastio, L. Xu, M. Kelliher, P. Kastner, S. Chan, J. C. Aster, Blood 2010, 116, 5455.

[64] R. E. Moellering, M. Cornejo, T. N. Davis, C. Del Bianco, Nature 2009, 462, 182.

[65] L. Astudillo, T. G. Da Silva, Z. Wang, X. Han, K. Jin, J. VanWye, X. Zhu, K. Weaver, T. Oashi, P. E. M. Lopes, D. Orton, L. R. Neitzel, E. Lee, R. Landgraf, D. J. Robbins, A. D. MacKerell, A. J. Capobianco, Cancer Res. 2016, 76, 3593 .

[66] C. Hurtado, A. Safarova, M. Smith, R. Chung, A. A. N. Bruyneel, J. GomezGaleno, F. Oswald, C. J. Larson, J. R. Cashman, P. Ruiz-Lozano, P. Janiak, T. Suzuki, M. Mercola, Sci. Rep. 2019, 9, 10811.

[67] R. Lehal, J. Zaric, M. Vigolo, C. Urech, V. Frismantas, N. Zangger, L. Cao, A. Berger, I. Chicote, S. Loubéry, S. H. Choi, U. Koch, S. C. Blacklow, H. G. Plamer, B. Bornhauser, M. González-Gaitán, Y. Arsenijevic, V. Zoete, J. C. Aster, J.-P. Bourquin, F. Radtke, Proc. Natl Acad. Sci. USA 2020, 117, 16292.

\section{License and Terms}

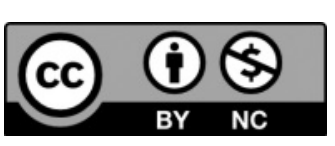

This is an Open Access article under the terms of the Creative Commons Attribution License CC BY_NC 4.0. The material may not be used for commercial purposes.

The license is subject to the CHIMIA terms and conditions: (http:// chimia.ch/component/sppagebuilder/?view=page\&id=12).

The definitive version of this article is the electronic one that can be found at https://doi.org/10.2533/chimia.2020.779 